\title{
THE METABOLISM OF AMINO ACIDS IN DIABETES MELLITUS
}

\author{
BY JOHN A. LUETSCHER, JR. \\ (From the Chemical Division, Medical Clinic, Johns Hopkins University and Hospital, Baltimore)
}

(Received for publication November 13, 1941)

The amino acid content of fasting human blood appears to be quite constant. Extensive surveys (1) have revealed only a few diseases in which the blood amino acid level is modified significantly. Acute yellow atrophy of the liver is associated with a rise in amino acids in the blood, whereas hypoaminoacidemia has been reported in patients with nephrosis and in pneumococcal pneumonia (2).

Concerning the fasting amino acid level in diabetes mellitus there is little agreement. Several investigators $(1 \mathrm{a}, 3)$ have observed elevated amino acid levels in a few of their diabetic subjects. Greene, Sandiford and Ross (1b) studied 116 diabetics and observed that the average amino acid level was within normal limits. No accurate data on the condition or treatment of these patients were given. On the other hand, a high blood amino acid content has been reported in dogs with experimentally induced diabetes (4).

Luck, Morrison and Wilbur (5) observed that insulin lowered the amino acid content of blood in both experimental animals and normal human subjects. These results have been confirmed by several investigators (6) using the Folin colorimetric method and by Farr and Alpert (7) using Van Slyke and MacFadyen's manometric ninhydrin method (8). Luck also studied two diabetic patients under insulin treatment and observed low normal fasting amino acid levels.

The lack of agreement of existing data on the blood amino acid content in human diabetes mellitus, together with the paucity of data on the clinical condition and therapy of the patients, suggested the present study.

\section{METHODS}

1. Choice of subjects. A group of twelve severe untreated diabetic patients was studied. All of these patients were admitted to the Johns Hopkins Hospital primarily because of diabetes, although complications (alveolar abscess, chronic sinusitis, chronic infection of hand) were present in several instances. In four of the twelve patients, the $\mathrm{CO}_{2}$ combining power was above 50 volumes per cent on admission. The other eight patients were in moderate to severe acidosis (Table I).
2. Method of study. In all cases, blood was drawn immediately after entry. In no case had nourishment been taken in the preceding three hours. Subsequent blood specimens were then drawn at various intervals during the course of therapy. The patients with severe acidosis were given hourly injections of insulin, with supplementary carbohydrate as indicated. Nitrogen balance studies were made on two patients.

In three of the patients, glycine ( 0.27 gram per kilo) was given intravenously and the effect on the blood and urinary amino acid, urea, and sugar levels was studied. From these data, the rate of deamination was estimated. These patients were studied subsequently during insulin treatment.

3. Chemical methods. The amino acid content of the blood plasma was determined by the manometric ninhydrin method of Van Slyke and MacFadyen (8b). This method is considered to be more specific than previous methods, and gives somewhat lower values. Normal limits, as given by Farr and MacFadyen (2a), are 3.6 to $5.4 \mathrm{mgm}$. calculated as nitrogen per $100 \mathrm{cc}$. of plasma. Most of the determinations were done in duplicate, and all determinations were checked with blank and known samples. In two cases, the results were compared with those of the colorimetric method of Folin (11). Analysis of urine for amino acid content was made by the manometric ninhydrin method. The low concentration of amino acids and the high concentration of substances which may give false reactions in urine make these values less significant than the blood determinations.

Since the manometric ninhydrin method depends on the measurement of evolved carbon dioxide, other reactions resulting in the production of carbon dioxide from diabetic plasma must be considered. Pre-existing carbon dioxide and bicarbonate are removed and thus cannot affect the result. The possibility of a slow evolution of carbon dioxide from some abnormal constituent of the blood was ruled out by performing the analysis with ninhydrin omitted. No carbon dioxide was produced under these conditions. The reaction of abnormal constituents with ninhydrin is also possible. This is ruled out as an important factor by the similarity of results obtained by the manometric ninhydrin method and by Folin's colorimetric method.

The urea content of blood and urine was determined by the urease method and the non-protein nitrogen by the micro-Kjeldahl.

\section{RESULTS}

\section{Plasma amino acid levels in untreated diabetes}

All twelve of the untreated diabetic patients had a plasma amino acid content exceeding the 
TABLE I

Chemical changes following insulin therapy in diabetic patients

\begin{tabular}{|c|c|c|c|c|c|c|c|c|}
\hline \multirow[b]{2}{*}{$\begin{array}{c}\text { Case } \\
\text { num- } \\
\text { ber }\end{array}$} & \multirow[b]{2}{*}{$\begin{array}{c}\text { Time } \\
\text { after ad- } \\
\text { mission }\end{array}$} & \multicolumn{5}{|c|}{ Blood } & \multicolumn{2}{|c|}{ Urine } \\
\hline & & $\underset{\mathbf{N}}{\text { Plasma }}$ & $\underset{\mathbf{N}}{\text { Urea }}$ & $\begin{array}{c}\text { NPN } \\
\text { total }\end{array}$ & Sugar & $\begin{array}{c}\text { Plasma } \\
\mathrm{CO}_{2} \\
\text { com- } \\
\text { bining } \\
\text { power }\end{array}$ & Sugar & $\begin{array}{l}\text { Ace- } \\
\text { tone }\end{array}$ \\
\hline & & \multicolumn{4}{|c|}{ mgm. per $100 \mathrm{cc}$. } & $\begin{array}{l}\text { oolumes } \\
\text { per cent }\end{array}$ & & \\
\hline 1 & $\begin{array}{c}0 \\
3 \text { weeks }\end{array}$ & $\begin{array}{r}19.8 \\
4.8\end{array}$ & $\begin{array}{l}16 \\
13\end{array}$ & $\begin{array}{l}42 \\
26\end{array}$ & $\begin{array}{l}182 \\
235\end{array}$ & $\begin{array}{l}55 \\
58\end{array}$ & $\begin{array}{l}4+ \\
4+\end{array}$ & $\begin{array}{l}4+ \\
0\end{array}$ \\
\hline 2 & $\begin{array}{l}0 \\
1 \text { day } \\
2 \text { days }\end{array}$ & $\begin{array}{r}17.3 \\
5.5 \\
4.5\end{array}$ & $\begin{array}{l}41 \\
21\end{array}$ & $\begin{array}{l}80 \\
46 \\
40\end{array}$ & $\begin{array}{r}768 \\
60 \\
420\end{array}$ & $\begin{array}{l}19 \\
59 \\
65\end{array}$ & $\begin{array}{l}4+ \\
0 \\
4+\end{array}$ & $\begin{array}{c}4+ \\
\text { trace } \\
0\end{array}$ \\
\hline 3 & \begin{tabular}{|c|}
0 \\
1 day \\
2 days \\
3 days \\
5 days \\
7 days \\
10 days
\end{tabular} & $\begin{array}{r}15.0 \\
5.5 \\
5.8 \\
4.6 \\
4.9 \\
5.6 \\
5.0\end{array}$ & $\begin{array}{l}23 \\
17 \\
15\end{array}$ & $\begin{array}{l}58 \\
36 \\
29\end{array}$ & $\begin{array}{l}396 \\
213 \\
200 \\
150 \\
200 \\
490 \\
192\end{array}$ & $\begin{array}{l}28 \\
48 \\
43 \\
\\
\\
51 \\
58\end{array}$ & $\begin{array}{c}4+ \\
2+ \\
2+ \\
0 \\
2+ \\
4+ \\
\text { trace }\end{array}$ & $\begin{array}{l}4+ \\
\text { trace } \\
\text { trace } \\
0 \\
0 \\
0 \\
0\end{array}$ \\
\hline 4 & $\begin{array}{l}0 \\
1 \text { day } \\
8 \text { days }\end{array}$ & $\begin{array}{r}14.5 \\
7.2 \\
5.1\end{array}$ & $\begin{array}{l}35 \\
23 \\
14\end{array}$ & $\begin{array}{l}68 \\
46 \\
30\end{array}$ & $\begin{array}{l}470 \\
105 \\
207\end{array}$ & $\begin{array}{l}31 \\
60\end{array}$ & $\begin{array}{l}4+ \\
0 \\
1+\end{array}$ & $\underset{0}{3+}$ \\
\hline 5 & $\begin{array}{ll} & 0 \\
1 & \text { day } \\
2 & \text { days }\end{array}$ & $\begin{array}{r}13.4 \\
8.1 \\
5.3\end{array}$ & $\begin{array}{l}17 \\
10 \\
10\end{array}$ & $\begin{array}{l}40 \\
26\end{array}$ & $\begin{array}{l}500 \\
226 \\
170\end{array}$ & $\begin{array}{l}12 \\
43 \\
54\end{array}$ & $\begin{array}{l}4+ \\
4+ \\
0\end{array}$ & $\begin{array}{l}4+ \\
1+ \\
0\end{array}$ \\
\hline 6 & $\begin{array}{c}0 \\
2 \text { days }\end{array}$ & $\begin{array}{r}12.5 \\
5.1\end{array}$ & $\begin{array}{l}25 \\
12\end{array}$ & $\begin{array}{l}52 \\
27\end{array}$ & $\begin{array}{l}261 \\
225\end{array}$ & $\begin{array}{l}23 \\
64\end{array}$ & $\begin{array}{l}4+ \\
3+\end{array}$ & $\begin{array}{l}4+ \\
0\end{array}$ \\
\hline 7 & $\begin{array}{c}0 \\
1 \text { day } \\
2 \text { days } \\
4 \text { days } \\
6 \text { days } \\
15 \text { days }\end{array}$ & $\begin{array}{r}10.8 \\
5.8 \\
4.7 \\
5.5 \\
5.4 \\
5.1\end{array}$ & $\begin{array}{l}45 \\
32 \\
20 \\
13\end{array}$ & $\begin{array}{l}74 \\
62 \\
40 \\
28 \\
24 \\
30\end{array}$ & $\begin{array}{r}840 \\
96 \\
220 \\
260 \\
179 \\
135\end{array}$ & $\begin{array}{l}32 \\
53 \\
47 \\
58 \\
55 \\
60\end{array}$ & $\begin{array}{c}4+ \\
0 \\
1+ \\
2+ \\
\text { trace } \\
0\end{array}$ & $\begin{array}{l}4+ \\
1+ \\
0 \\
0 \\
0 \\
0\end{array}$ \\
\hline 8 & $\begin{array}{l}0 \\
1 \text { day } \\
2 \text { days } \\
3 \text { days }\end{array}$ & $\begin{array}{r}10.3 \\
6.1 \\
5.4 \\
5.3\end{array}$ & $\begin{array}{l}16 \\
13\end{array}$ & $\begin{array}{l}36 \\
30\end{array}$ & $\begin{array}{l}300 \\
177 \\
195 \\
195\end{array}$ & $\begin{array}{l}43 \\
50 \\
54 \\
58\end{array}$ & $\begin{array}{l}4+ \\
0 \\
0 \\
0\end{array}$ & $\begin{array}{c}3+ \\
\text { trace } \\
0 \\
0\end{array}$ \\
\hline 9 & $\begin{array}{c}0 \\
8 \text { days }\end{array}$ & $\begin{array}{l}9.6 \\
5.9\end{array}$ & $\begin{array}{l}14 \\
13\end{array}$ & $\begin{array}{l}34 \\
27\end{array}$ & $\begin{array}{l}436 \\
130\end{array}$ & 55 & ${ }_{0}^{4+}$ & $\begin{array}{l}2+ \\
0\end{array}$ \\
\hline 10 & $\begin{array}{c}0 \\
1 \text { day }\end{array}$ & $\begin{array}{l}9.5 \\
5.0\end{array}$ & $\begin{array}{l}13 \\
10\end{array}$ & $\begin{array}{l}43 \\
28\end{array}$ & $\begin{array}{l}496 \\
149\end{array}$ & $\begin{array}{r}9 \\
56\end{array}$ & $\begin{array}{l}4+ \\
0\end{array}$ & $\begin{array}{c}4+ \\
\text { trace }\end{array}$ \\
\hline 11 & $\begin{array}{c}0 \\
12 \text { days }\end{array}$ & $\begin{array}{l}8.3 \\
5.9\end{array}$ & $\begin{array}{l}15 \\
14\end{array}$ & $\begin{array}{l}30 \\
25\end{array}$ & $\begin{array}{l}348 \\
142\end{array}$ & 52 & $\begin{array}{l}4+ \\
0\end{array}$ & $\begin{array}{l}4+ \\
0\end{array}$ \\
\hline 12 & $\begin{array}{c}0 \\
2 \text { days } \\
3 \text { days } \\
5 \text { days } \\
10 \text { days }\end{array}$ & $\begin{array}{l}7.5 \\
5.7 \\
5.5 \\
5.3 \\
5.8\end{array}$ & $\begin{array}{l}17 \\
12\end{array}$ & $\begin{array}{l}34 \\
28 \\
26\end{array}$ & $\begin{array}{r}230 \\
118 \\
132 \\
105 \\
90\end{array}$ & 60 & $\begin{array}{c}4+ \\
1+ \\
\text { trace } \\
0 \\
0\end{array}$ & $\begin{array}{l}2+ \\
\text { trace } \\
0 \\
0 \\
0\end{array}$ \\
\hline
\end{tabular}

normal fasting level (Table I). In eight cases, the content was greater than $10 \mathrm{mgm}$. per $100 \mathrm{cc}$. This value probably exceeds the upper limit of even normal post-absorptive rise. In the other four cases, the fasting levels exceeded the normal fasting upper limit of $5.4 \mathrm{mgm}$. per $100 \mathrm{cc}$. The amino acid content of whole blood and of packed red blood cells was similarly increased, the erythrocytes maintaining a slightly higher level than the plasma. In two cases the amino acid levels obtained by the ninhydrin method were compared with determinations of amino acids by the colorimetric method of Folin. The results of the two methods were very similar. The colorimetric method yielded slightly lower values when the manometric ninhydrin results were very high, while at normal levels, the ninhydrin method gave slightly lower values.

\section{Relation of blood amino acid content to the degree of acidosis or azotemia}

The highest amino acid level was recorded in a patient with a normal plasma $\mathrm{CO}_{2}$ combining power (Case 1). It is to be noted, however, that all of the patients in diabetic acidosis had a significantly elevated blood amino acid content. Strong tests for acetone and diacetic acid in the urine were always noted when the blood amino acid content was much above normal. There was no correlation between the blood content of amino acids and that of urea.

\section{Amino acid content of urine}

The loss of substances reacting as amino acids in the urine was much increased in patients with severe diabetes. This fact has been noted (9). Untreated diabetics excreted from four to ten times the normal quantity of amino acids in the urine (Figure 2).

\section{Effect of insulin}

The elevated amino acid content of untreated diabetics was restored to normal by insulin therapy (Table I). During the first few hours of intensive insulin therapy the decrease in blood amino acids roughly paralleled the reduction in blood sugar in a patient with severe acidosis (Figure 1). Within twelve to forty-eight hours, the plasma amino acid level attained normal or even subnormal values. From this point onward, the amino acid level was rather constant, provided that sufficient insulin and carbohydrate were given. A considerable dissociation between the twentyfour-hour curves of blood concentration of sugar 


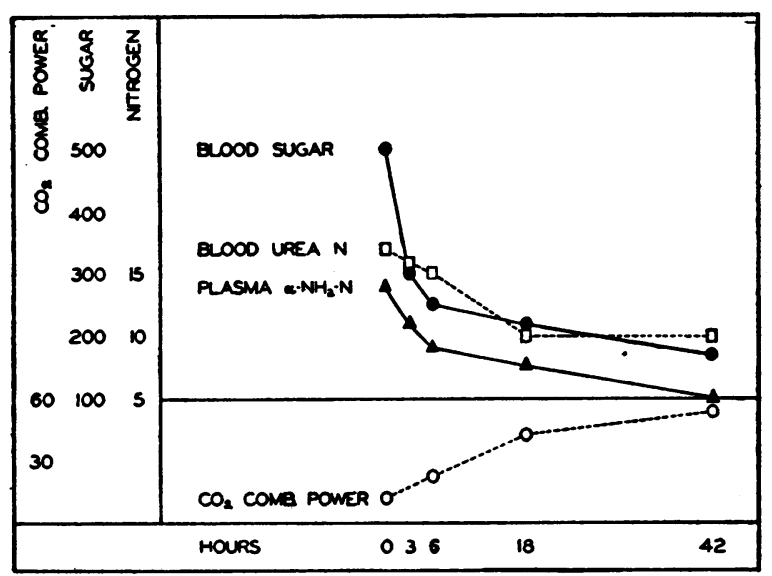

Fig. 1. Changes in Concentration of Various Substances in the Blood During the First Forty-two Hours of Treatment of a Patient with Severe DiaBETIC ACIDOsIS

There is a rough parallelism between the falling concentration curves of blood sugar and amino acids.

and amino acid was observed during the period of adjustment of diet and insulin, since there were frequently proportionately larger and more rapid variations in the blood sugar. Hypoaminoacidemia (below $3.6 \mathrm{mgm}$. $\mathrm{N}$ per cent) was rarely seen following large doses of insulin. Whether hypoglycemia occurred at the same time depended on the carbohydrate intake.

The effect of insulin on the increased renal excretion of nitrogen in uncontrolled diabetes is well known. In the two patients in whom nitrogen excretion studies were made, the fall in the blood amino acid level occurred somewhat more abruptly than the diminution of renal nitrogen excretion. The disappearance of acetone and diacetic acid from the urine also lagged behind the fall of blood amino acid.

\section{Tolerance and utilization of intravenously injected glycine}

The high blood level of amino acids in uncontrolled diabetes presumably arises from some disturbance in production or utilization. In order to study certain aspects of this problem, glycine $(0.27$ gram per kilo) was injected intravenously in 10 per cent solution over a period of forty-five minutes and the blood amino acid, urea, and sugar were followed for the subsequent three-hour period. Urine was collected during a control period before the test, and hourly during the test. The patients were given the glycine before insulin therapy had been instituted. The same routine was repeated subsequently in two of the patients after they were well balanced on protamine zinc insulin, the test being performed in the early morning, ten hours following the last nourishment, and nearly twenty-four hours after the last insulin injection. Similar tests were performed on normal subjects. Data are presented graphically in Figure 2.

It is evident that the uncontrolled diabetic patient responded to the injection of a moderate amount of glycine in a considerably different fashion from a normal subject, or from an insulintreated diabetic. In untreated severe diabetes, the plasma amino acid level started from, and rose to, higher levels. Loss of amino acid in the urine was increased. A large rise in blood urea was not observed. There was a considerable increase in urea excretion, however, which during the course of three hours was equivalent to a large proportion of the nitrogen of the injected glycine. There was also a significant rise in blood sugar and in urinary sugar excretion. In contrast, the insulin-treated diabetic patient and the normal individual show much smaller changes than the severe untreated diabetic, although the direction of each reaction appears to be the same.

\section{DISCUSSION}

These observations indicate that the plasma amino acid content is greatly elevated in untreated severe diabetes. Concomitantly, the urinary output of amino acids is considerably increased. The increased blood amino acid level does not appear to be due to impairment of excretory function of the kidney, since the output of amino acid is increased above the normal. In addition, there is no correlation between urea retention and the increase of amino acid in the blood. The degree of ketonemia does not affect the plasma amino acid content significantly.

Insulin has a rapid and profound effect in lowering the elevated blood amino acid level. During the first few hours of insulin treatment, the falling curves of blood amino acids and sugar are roughly parallel. When carbohydrate is administered, however, the parallelism ceases. The plasma amino acid content remains rather con- 


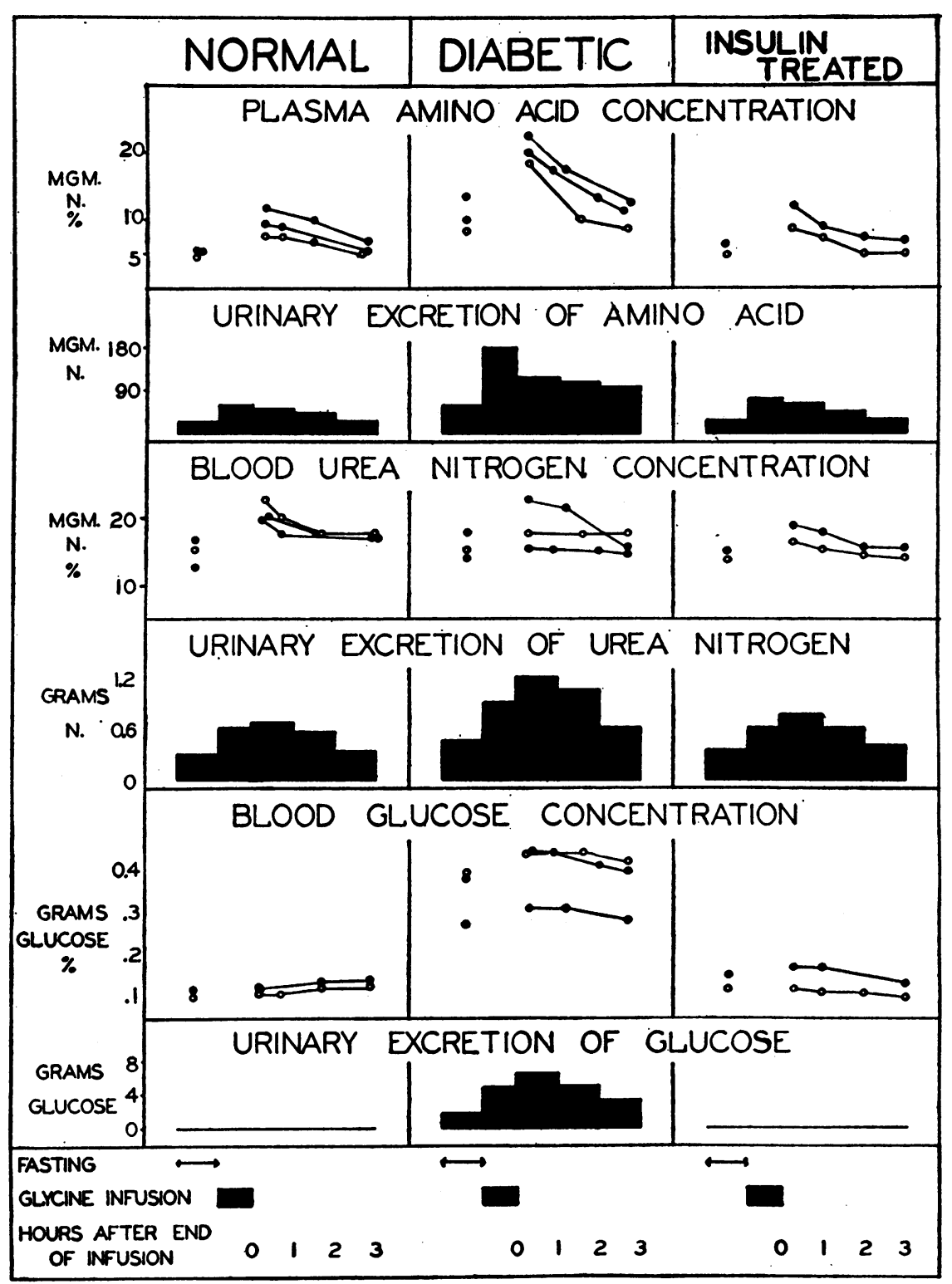

Fig. 2. Graphic Summary of Results of Intranenous Amino Acid Tolerance Curves in Normal Subjects and in Severe Diabetic Patients Before and After INSULIN THERAPY

stant under insulin therapy, and the fasting and post-absorptive levels are well within normal limits. In contrast, during the same period the blood sugar level may show wide swings. A similar effect was observed by Luck and Morse (10) in normal humans when the maintenance of a normal blood sugar did not prevent or diminish appreciably the lowering of the normal blood amino acid content by large doses of insulin.
When insulin is administered to a severe diabetic, there is a rapid diminution in renal excretion of urea. This occurred a few hours after the fall in amino acids in the two cases studied. There is also a difference in the handling of intravenously injected glycine by diabetic patients before and after insulin therapy. Plasma amino acids reached higher levels in the untreated patients, and more glycine was lost in the urine 
(Figure 2). There is also an unusually large increase in urea nitrogen excretion in the untreated diabetics following glycine injection. The changes in blood and urine urea and glucose (Figure 2) superficially suggest an increased rate of deamination and gluconeogenesis, but with the limited data, it is not possible to be certain. One can be certain, however, that in the severe untreated diabetic, the rate of urea production from amino acids is at least equal to normal.

If there is no decrease in the rate of deamination of amino acids in severe untreated diabetes, the increased concentration of plasma amino acids would appear to be due to an increase in the rate of production or liberation of amino acids. Conversely, insulin would appear to diminish the rate of production or liberation of amino acids, since insulin lowers the concentration of plasma amino acids at a time when the production of urea is diminishing. A similar conclusion on the action of insulin was reached by Mirsky (6a) in his studies on nephrectomized non-diabetic animals.

\section{SUMMARY AND CONCLUSIONS}

1. Twelve patients with severe untreated diabetes mellitus had high fasting plasma amino acid levels.

2. The high plasma levels were accompanied by increased urinary excretion of amino acids, and could not be correlated with urea retention.

3. The administration of insulin caused a rapid return of blood levels to normal. On continued insulin therapy, the plasma amino acid was maintained at normal levels, despite the fluctuation of the blood sugar.

4. Evidence suggests that in severe untreated diabetes mellitus, there is an increase in the rate of production or liberation of amino acids, and that the administration of insulin is followed by the return to a more normal rate.

The author is greatly indebted to Doctor George W. Thorn for helpful suggestions and criticism of this work.

\section{BIBLIOGRAPHY}

1a. Desqueyroux, J., Recherches cliniques sur l'aminoacidemia. Ann. de méd., 1923, 13, 20. b. Greene, C. H., Sandiford, K., and Ross, H., The amino acid content of the blood in normal and pathologic conditions. J. Biol. Chem., 1924, 58, 845.

c. Feinblatt, H. M., and Shapiro, I., The amino acid content of blood in various pathologic conditions. Arch. Int. Med., 1924, 34, 690.

d. Edgar, S. H., The amino acid content of the blood of children in health and disease. Biochem. J., 1928, 22, 168.

2a. Farr, L. E., and MacFadyen, D. A., Hypoaminoacidemia in children with nephrotic crises. Am. J. Dis. Child., 1940, 59, 782.

b. Farr, L. E., MacLeod, C. M., Futcher, P. H., Emerson, K., Mirick, G. S., and Curnen, E. C., Hypoaminoacidemia in patients with pneumococcal pneumonia. Proc. Soc. Exper. Biol. and Med., 1940, 44, 290.

3. Wolpe, G., Ueber Aminosauren im Blutserum, im Liquor Cerebrospinalis, und in Punktionflussigkeiten. München. med. Wchnschr., 1924, 71, 363.

4. Okada, S., and Hayashi, T., Studies on the amino acid nitrogen content of the blood. J. Biol. Chem., 1922, 51, 121.

5. Luck, J. M., Morrison, G., and Wilbur, L. F., The effect of insulin on the amino acid content of blood. J. Biol. Chem., 1928, 77, 151.

6a. Mirsky, I. A., The influence of insulin on the protein metabolism of nephrectomized dogs. Am. J. Physiol., 1938, 124, 569.

b. Kerr, S. E., and Krikorian, V. H., The effect of insulin on the distribution of non-protein nitrogen in the blood. J. Biol. Chem., 1929, 81, 421.

c. Powers, H. H., and Reis, F., The effect of insulin on amino acid and urea nitrogen in laked and unlaked blood. J. Biol. Chem., 1933, 101, 523.

7. Farr, L. E., and Alpert, L. K., The effect of endocrine extracts on the amino acids in the blood, with incidental findings on the blood sugar and urea. Am. J. Physiol., 1940, 128, 772.

8a. Van Slyke, D. D., and Dillon, R. T., Gasometric determination of carboxyl groups in amino acid. Compt. rend. Lab. Carlsberg, series chim., 1938, 22, 480.

b. Personal communication of plasma method to be published by Van Slyke and MacFadyen.

9a. Galambos, A., and Tausz, B., Ueber Eiweissstoffwechsel bei Diabetes Mellitus. Z. Klin. Med., 1913, 77, 14.

b. Labbé, M., and Bith, H., L'amino-acidurie Pathologique. Presse Med., 1913, 21, 698.

10. Luck, J. M., and Morse, S. W., Effects of insulin and adrenalin on the amino acid content of blood. Biochem. J., 1933, 27, 1648.

11. Folin, O., A system of blood analysis. Supplement III. A new colorimetric method for the determination of the amino acid nitrogen in blood. J. Biol. Chem., 1922, 51, 393. 